\title{
Kinerja Balai Penyuluhan Pertanian (BPP) dan Dampaknya pada Perilaku Petani Padi di Sulawesi Selatan)
}

\section{The Performances of Rural Extension Center (BPP) and Their Impacts to the Behaviors of Ricefield Farmers in South Sulawesi}

\author{
Muh. Hatta Jamil ${ }^{1}$, Amri Jahi ${ }^{2}$, Darwis S. Gani ${ }^{2}$, \\ Ma'mun Sarma ${ }^{2}$, I Gusti Putu Purnaba ${ }^{2}$ \\ ${ }^{1}$ Fakultas Pertanian, Universitas Hasanuddin, Makassar-Sulawesi Selatan \\ ${ }^{2}$ Institut Pertanian Bogor
}

Abstract

\begin{abstract}
This research was aimed to know factors related to the action programs as a representation of BPP performance and relationship between factors that potentially increase BPP performance and their impacts to the behavioral changes of ricefield farmers in South Sulawesi. Population of this research were all BPP located in 15 districts (regencies) in South Sulawesi (176 subdistricts 150 BPP). Determination of samples used Slovin method, number of samples was 109 BPP located within 109 subdistricts. Research design was done based on the ex post facto with method design of survey and interviews using questionnaires. Design of data analysis used approach of Structural Equation Modeling (SEM) model applying LISREL program. Results of the research showed that variables of BPP development, BPP management, human resources, guided farmers, BPP resources, and BPP adaptation were significantly influencing the action programs as BPP representative performances with correlation coefficient (R2) was 0.72, the remaining 28 percent was affected by other factors outside of the study. Those factors directly influenced each others both insignificant and significant at $\alpha=0.05$. Besides that, they also indirectly influenced farmer behavior as much as 0.78 unit. The influence of action program as representation of BPP performances to the farmer behavior was indicated by correlation coefficient (R2) of 0.61 , the remaining 39 percent was influenced by other variables outside of the study. Strategic implication of this research become important to the farmer behaviors, and to the development of BPP performances through action programs to a better direction by considering BPP development, BPP management, human resources, guided farmers, BPP resources and BPP adaptation.
\end{abstract}

Keywords : Performances, development, management, resources, adaptation, action program, farmer behavior; BPP

Abstrak

Kinerja BPP dapat direpresentasikan dengan pendekatan proses sebagai sistem organisasi terbuka (open organization system). Pendekatan tersebut, menunjukkan proses pelaksanaan fungsi BPP dengan pemanfaatan sumberdaya (hardware and software,, technoware, humanware, infoware, dan Manageware). Sehingga proses tersebut, dapat ditelaah dengan memahami unsurunsurnya yaitu: (i) inputs, (ii) transformation process, (iii) outputs, (iv) feedback, dan (v) environment. Kinerja BPP tercermin dari rumusan dan penjabaran serta pelaksanaan rencana strategis dan rencana aksi hubungannya dengan karakteristik BPP, keunggulan mutu BPP, sumberdaya manusia BPP, sarana dan pembiayaan, rencana strategis dan rencana aksi yang berhubungan dengan perilaku petani. Tujuan penelitian untuk mengetahuai faktor-faktor yang berhubungan dengan kinerja BPP dan identifikasi faktor-faktor internal yang dapat meningkatkan kinerja BPP serta mengkaji dampaknya terhadap perubahan perilaku petani di Sulawesi Selatan. Populasi penelitian adalah seluruh BPP yang terdapat di $15 \mathrm{Kab}$ pada setiap kecamatan di Sulawesi Selatan (176 Kecamatan/150 BPP).Penentuan sampel menggunakan metode Slovin, sehingga jumlah sampel sebanyak 109 BPP yang berkedudukan di 109 Kecamatan pada 15 Kabupaten di Sulawesi Selatan.Desain penelitian menggunakan metode survey dan wawancara dengan menggunakan kuesioner. Sedangkan desain analisis data dilakukan dengan pendekatan model Structural Equation Modeling (SEM) yang menggunakan program LISERAL.

Kata Kunci: Kinerja, Sumberdaya BPP, rencana strategis, rencana aksi, perilaku petani

\section{Pendahuluan}

Organisasi penyuluhan pertanian telah mengalami "disorganisasi" saat Indonesia memasuki era otonomi daerah. Kebijaksanaan desentralisasi tersebut berimplikasi juga terhadap struktur dan nomenklatur organisasi penyuluhan. Misalnya, BPP diubah dengan namaKantor Cabang Dinas Pertanian, UPTD, BPK, KIP, Bagian Unit Kerja dalamDinas. Implikasi lainnya, sumberdaya yang dibutuhkan (sarana prasarana dan pembiayaan) untuk melaksanakan tugas BPP secara khusus dan

\footnotetext{
${ }^{1}$ Korespondensi penulis

E-mail: hattaj@yahoo.com
} 
organisasi penyuluhan pertanian secara umum semakin minim dan bahkan tidak jelas. BPP yang kedudukannya ditingkat kecamatan sesungguhnya merupakan titik sentral dalam struktur organisasi penyuluhan. Dapat dikatakan sebagai organisasi penyelenggaraan perubahan, karena BPP menerima pelimpahan tugas dari atas atau menerjemahkan kebijakan yang dirumuskan dari struktur atas, tetapi juga dituntut memahami permasalahan dan mengakomodir aspirasi dari bawah (petani), dan menyelenggaran penyuluhan pada wilayahnya.

Kinerja BPP tercermin dari rumusan dan penjabaran serta pelaksanaan programaksi hubungannya dengan pengembangan BPP, pengelolaan BPP, sumberdaya manusia BPP, petani binaan, sumberdaya BPP, Adaptasi BPP, dan program aksi yang berhubungan dengan perilaku petani. Kinerja BPP yang berkembang dan meningkat, tentunya kemampuan dan keterampilan diri anggota dapat membentuk kinerja yang baik yang pada akhirnya mendorong kinerja BPP yang semakin meningkat. Selain itu, juga dapat mendorong ke arah kompetensi dan partisipasi klien yang semakin tinggi dan pada akhirnya akan membantu klien meningkatkan pendapatan dan kesejahteraan petani dan keluarganya.

Tujuan penelitian adalah: (1) Mengidentifikasi faktor-faktor internal yang dapat meningkatkan kinerja BPP dalam bentuk program aksi padapengembangan usahatani padi di Sulawesi Selatan, (2) Mengkaji pengaruh faktor-faktor internal, program aksi BPP pada perilaku petani dalam berusahatani padi di Sulawesi Selatan, (3) Mengkaji derajat hubungan faktor-faktor internal yang berpengaruh pada program aksi BPP dalam mengembangkan usahatani padi di Sulawesi Selatan, dan (4) Mengkaji dampak program aksi BPP terhadap perubahan perilaku petani padi di Sulawesi Selatan.

Kegunaan penelitian adalah : (1) Penelitian ini diharapkan berguna dan bermanfaat bagi organisasi penyuluhan pertanian (BPP) dalam merumuskan kebijakan pengembangan kinerja organisasi penyuluhan pertanian, (2) Dapat berkontribusi terhadap pembaruan organisasi penyuluhan pertanian (BPP) sebagai ujung tombak organisasi penyelenggaraan penyuluhan pertanian di lapangan, (3) Dapat dijadikan dasar perumusan dan implementasi kebijakan pengembangan organisasi penyuluhan pertanian serta dapat menjadi bahan penilaian dan pengembangan kinerja organisasi penyuluhan pertanian, (4) Bahan pengembangan ilmu pengetahuan pada bidang ilmu penyuluhan pembangunan "khususnya organisasi penyuluhan pertanian" untuk kepentingan dan kesejahteraan masyarakat, dan (5) Berkontribusi bagi peneliti dan calon peneliti megembangkan model program aksi serta kinerja organisasi penyuluhan.

\section{Metode Penelitian}

Desain penelitian ini adalah desain analitis yang dikerjakan berdasarkan data ex post facto, sebagai bentuk penelitian yang menganalisis dan menilai peristiwa faktual yang terjadi di lapangan (Babbie, 1992; Nazir, 2003). Metode penelitian yang digunakan adalah survey dengan desain kuesioner dan wawancara. Metode survey sering digunakan untuk mengoleksi data pada penelitian organisasi untuk menkaji ciri-ciri dan gejala yang secara langsung tampak (Ferdinand, 2006; Brewerton dan Millward, 2006; Swanson dan Holton III, 2005).

Populasi penelitian adalah seluruh BPP yang terdapat pada 15 kabupaten dan 176 kecamatan di Sulawesi Selatan dengan jumlah populasi BPP 150. Penarikan sampel dengan cara "contoh acak proporsional," sedangkan ukuran sampel dengan menggunakan rumus Slovin (Sevilla, 1993)diperoleh sebesar 109. Penelitian ini menggunakan validitas kerangka (construct validity) untuk menguji validitas alat ukur/kuesioner yang digunakan dengan cara menetapkan kerangka konsep, kemudian disusun tolok ukur operasionalnya, lalu ditetapkan indikatorindikator dari tiap peubah penelitian, selanjutnya dilakukan uji pakar, kemudian uji lapang instrumen. Data yang terkumpul dianalisis dengan uji reliabilitas menggunakan koefisien Cronbach Alpha dan hasilnya sebesar 0,843. Pengum-pulan data dilakukan pada bulan Agustus - Oktober 2011. Data yang terkumpul ditabulasi dan dianalisis menggunakan SEM (Structural Equation Modex.

\section{Hasil dan Pembahasan}

Setelah dilakukan analisis peubah yang berpengaruh terhadap program aksi BPP sebagai representasi kinerja BPP, ditemukan model struktural kinerja BPP yang menunjukkan jalur pengaruh antar peubah yang dapat dirumuskan persamaan model strukturalnya sebagai berikut: 
$0,54 X 4+0,15 X 4$

(2) $\quad \mathrm{Y} 2=0,78 \mathrm{Y} 1$

Gambar 1 memperlihatkan bahwa pengaruh langsung peubah pengembangan BPP, pengelolaan BPP, sumberdaya manusia, sumberdaya manusia, petani binaan, sumberdaya BPP, dan adaptasi BPP pada program aksi BPP dengan koefisien pengaruh

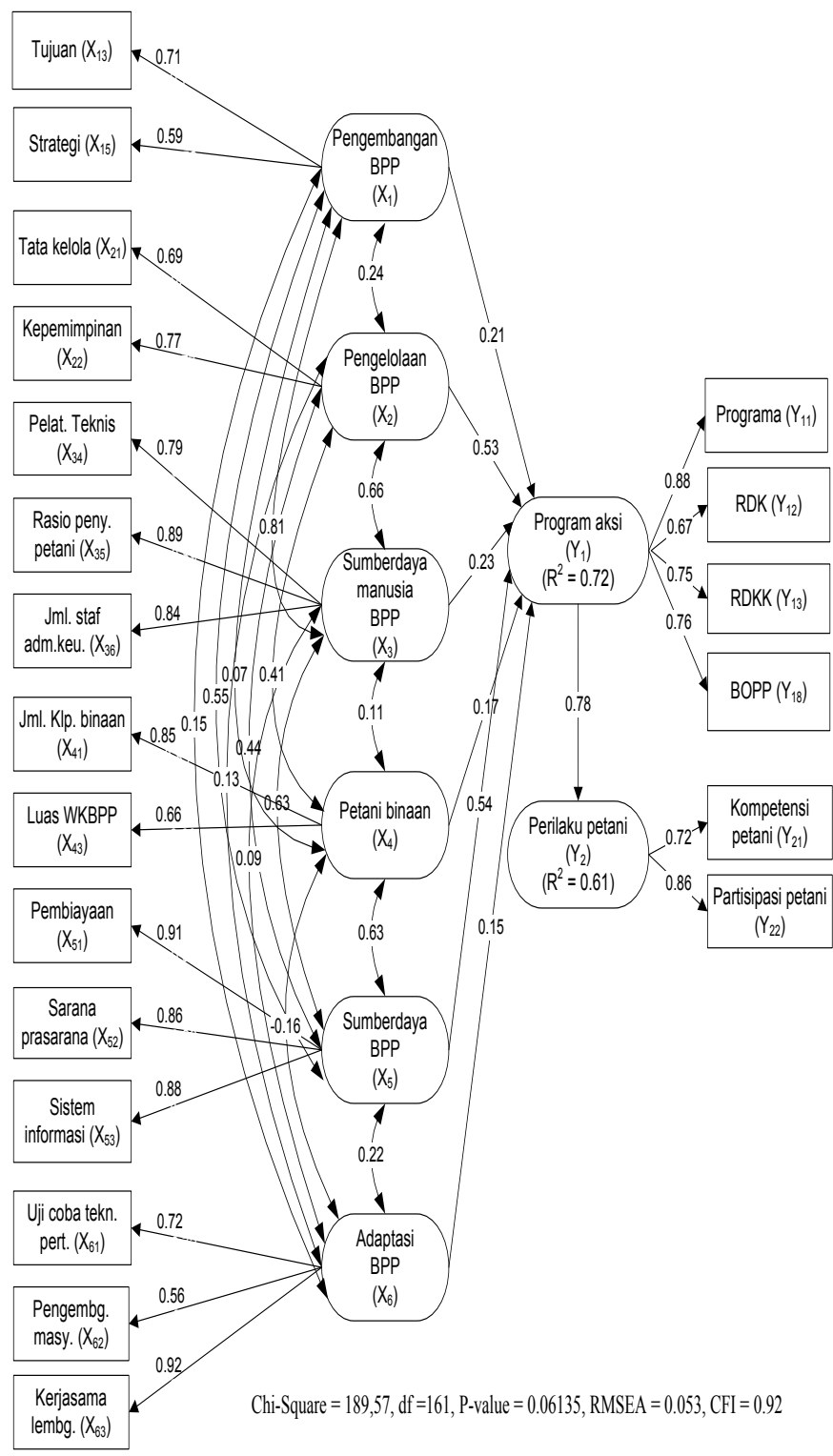

Keterangan: $\mathrm{X} 1=$ Pengembangan BPP,

$\mathrm{X} 2$ = Pengelolaan BPP,

$\mathrm{X} 3$ = Sumberdaya manusia,

$\mathrm{X} 4=$ Petani binaan

$\mathrm{X} 5$ = Sumberdaya BPP,

$\mathrm{X} 6=$ Adaptasi BPP

$\mathrm{Y} 1=$ Program aksi,

Y2 $=$ Perilaku petani

Gambar 3 Estimasi Parameter Model Struktural Kinerja BPP secara berurutan sebesar 0,$21 ; 0,53 ; 0,23 ; 0,17 ; 0,54$; 0,15 yang nyata pada $\alpha=0,05$. Sehingga secara matematik persamaan model struktural program aksi BPP sebagai berikut : Y $1=0,21 \mathrm{X} 1+0,53 \mathrm{X} 2$ $+0,23 \mathrm{X} 3+0,17 \mathrm{X} 4+0,54 \mathrm{X} 5+0,15 \mathrm{X} 6$; Secara bersama pengaruh keenam peubah tersebut pada program aksi sebesar 0,78 yang nyata pada $\alpha=0,05$. Pengaruh peubah pengembangan BPP, pengelolaan terhadap BPP, sumberdaya manusia, petani binaan, sumberdaya BPP, adaptasi BPP dan program aksi pada perilaku petani secara berurutan, yaitu: 0,14 ; 0,$16 ; 0,43 ; 0,37 ; 0,49 ; 0,17$ dan 0,78 yang nyata pada $\alpha=0,05$. Pengembangan BPP, pengelolaan BPP, sumberdaya manusia, petani binaan, sumberdaya BPP, adaptasi BPP dan program aksi berpengaruh secara tidak langsung pada perilaku para petani, sedangkan program aksi berpengaruh langsung pada perilaku petani, sehingga secara matematik persamaan model struktural perilaku petani adalah: $\mathrm{Y} 2=0,78 \mathrm{Y} 1$; Y2 merupakan perilaku petani dan Y1 merupakan program aksi. Arah dan koefisien hubungan antara peubah pengembangan BPP dan adaptasi BPP, pengembangan BPP dan sumberdaya $\mathrm{BPP}$, pengembangan BPP dan SDM, pengembangan BPP dan pengelolaan BPP, pengelolaan BPP dan adaptasi BPP, pengelolaan BPP dan sumberdaya BPP, pengelolaan BPP dan petani binaan, pengelolaan BPP dan SDM, SDM dan sumberdaya BPP, SDM dan petani binaan, petani binaan dan adaptasi BPP serta sumberdaya BPP dan adaptasi BPP. Koefisien hubungan antar peubah tersebut: 0,$15 ; 0,55 ; 0,81$; 0,$24 ; 0,13 ; 0,44 ; 0,41 ; 0,66 ; 0,63 ; 0,11 ; 0,63$ dan 0,22 yang nyata pada $\alpha=0,05$.

Gambar 1 menunjukkan pengaruh peubah program aksi pada perubahan perilaku petani secara berurutan, yaitu: 0,$78 ; 0,56$; dan 0,67 . Peubah program aksi berpengaruh tidak langsung pada kompetensi dan partisipasi petani padi, sehingga secara matematik persa-maan model struktural perilaku petani padi adalah: $\mathrm{Y} 2=0,78 \mathrm{Y} 1 ; \mathrm{Y} 2$ merupakan perilaku petani padi dan Y1 merupakan program aksi. Pada Gambar 1 juga memperlihatkan program aksi berpengaruh pada perilaku petani padi dengan koofisien determinasi (R2) sebesar 0,61 satuan.

\section{Pengaruh Pengembangan BPP pada Program Aksi}

Hasil penelitianmemperlihatkan bahwapeubah 
Tabel 1 Koefisien dan t-Hitung Pengaruh Peubah Pengembangan BPP, Pengelolaan BPP, Sumberdaya Manusia, Petani Binaan, Sumberdaya BPP, Adaptasi BPP dan Program Aksi Pada Perilaku Petani.

\begin{tabular}{lllccc}
\hline & & & \multicolumn{2}{c}{ Total Koefisien Pengaruh } & \\
& & & Langsung & Tidak langsung & t-hitung \\
& & & - & 0,14 & 2,56 \\
\hline Pengembangan BPP & $=======>$ & Perilaku petani & - & 0,16 & 2,38 \\
Pengelolaan BPP & $=======>$ & Perilaku petani & - & 0,43 & 4,45 \\
Sumberdaya manusia & $=======>$ & Perilaku petani & - & 0,37 & 2,89 \\
Petani binaan & $=======>$ & Perilaku petani & - & 0,49 & 4,48 \\
Sumberdaya BPP & $=======>$ & Perilaku petani & - & 0,17 & 2,43 \\
Adaptasi BPP & $=======>$ & Perilaku petani & - & - & 2,89 \\
Program aksi & $=======>$ & Perilaku petani & 0,78 & &
\end{tabular}

Keterangan : $\underline{t}_{0,05}$ tabel $=1,96$

pengembangan BPP secara langsung berpengaruh nyata pada program aksi BPP. Hal tersebut memberi artibahwa pengembangan BPPikut menentukan tingkat kualitas program aksi BPP dengan koefisien pengaruh sebesar 0,21 yang nyata pada $\alpha=0,05$. Pengaruh pengembangan program dapat terlihat pada kualitas perumusan programa penyuluhan pertanian, kuantitas dan kuantitas menfasilitasi pelaku utama menyusun RDK dan RDKK serta kemampuan mengelola biaya operasional sebagai energi menjalankan fungsi sebagai penyuluh dan staf BPP. Hal tersebut berarti, jika terjadi peningkatan satu satuan program aksi, akan meningkatkan kualitas programa sebesar 0,18 satuan, meningkatkan kemampuan fasilitasi RDK dan RDKK masing-masing sebesar 0,14 dan 0,16 satuan serta meningkatkan efisiensi dan efektifitas pemanfaatan BOPPdalammenjalankantugas danfungsinya. Dimensi pengaruh nyata pengembangan BPP pada program aksi adalah tujuan dan strategi BPP. Relevansi antara tujuan dan kinerja organisasi dikemukakan oleh Rummler dan Brache (1995), kinerja pada level organisasi ini terkait dengan tujuan organisasi, rancangan organisasi, dan manajemen organisasi. Ricard (2003) Mengemukakan bahwa kinerja merupakan seperangkat perilaku yang relevan dengan tujuan organisasi, unit organisasi tempat orang bekerja.Hasil penelitian memperlihatkan bahwa peubah pengembangan BPP secara langsung berpengaruh nyata pada program aksi BPP. Hal tersebut memberi artibahwa pengembangan BPP ikut menentukan tingkat kualitas program aksi BPP dengan koefisien pengaruh sebesar 0,21 yang nyata pada $\alpha=$ 0,05 .

\section{Pengaruh Pengelolaan BPP pada Program Aksi}

Penilitian ini menunjukkan bahwa peubah pengelolaan BPP berpengaruh nyata pada program aksi. Hal ini berarti Pengelolaan BPP turut menentukan terumuskan dan terimplementasikannya dengan baik program aksi BPP dengan koefisien pengaruh sebesar 0,53 yang nyata pada $\alpha=0,05$. Pengaruh pengelolaan BPP tersebut pada program aksi terlihat pada kemampuan BPP merumuskan programa penyuluhan, memfasilitasi RDK dan RDKK serta BPP mampu mengarahkan stafnya untuk memanfaatkan BOPP secara cermat dan bijak untuk menjalaskan tugastugas BPP dan menyelenggarakan proses belajar. Indikasinya, apabila terjadi peningkatan satu satuan pengelolaan BPP, akan meningkatkan program aksi merumuskan dan mengimplementasikan programa penyuluhan sebesar 0,47 dan secara bersamaan juga akan meningkatkan RDK sebesar 0,36, RDKK sebesar 0,40 dan BOPP sebesar 0,40 satuan.

Hasil penelitian ini searah dengan apa yang disusun oleh ADB (Asian Development Bank) Elemen tata kelola (governance) dengan istilah unsur-unsur tata pemerintahan (elements of governance), bergantung pada empat elemen kunci atau kondisi: akuntabilitas, (2) partisipasi, (3) prediktabilitas, dan (4) transparansi. UNDP juga menyusun elemen-elemen tentang governance, yaitu :(1) participatory, (2) transparent, (3) accountable, (4) equitable, dan (5) promotes the rule of law. Sedangkan penciri peubah kepemimpinan yang ditemukan dalam penelitian ini searah dengan pandangan Waldron et.al., dalam Swanson et. al., 
Jurnal Penyuluhan, September 2012 Vol. 9 No. 2

Tabel 2 Arah, Koefisien dan t-Hitung Hubungan Antar Peubah Pengembangan BPP, Pengelolaan BPP, Sumberdaya Manusia, Petani Binaan, Sumberdaya BPP, dan Adaptasi BPP

\begin{tabular}{lllcc}
\hline & Hubungan Antar Peubah & Arah/Koefisien Hubungan & t-hitung \\
\hline Pengembangan BPP & $<===>$ & Adaptasi BPP & 0,15 & 2,13 \\
Pengembangan BPP & $<===>$ & Sumberdaya BPP & 0,55 & 3,32 \\
Pengembangan BPP & $<===>$ & Petani binaan & 0,07 & 0,45 \\
Pengembangan BPP & $<===>$ & SDM & 0,81 & 4,96 \\
Pengembangan BPP & $<===>$ & Pengelolaan BPP & 0,24 & 2,42 \\
Pengelolaan BPP & $<===>$ & Adaptasi BPP & 0,13 & 1,97 \\
Pengelolaan BPP & $<===>$ & Sumberdaya BPP & 0,44 & 3,95 \\
Pengelolaan BPP & $<===>$ & Petani binaan & 0.41 & 3,39 \\
Pengelolaan BPP & $<===>$ & SDM & 0,66 & 3,46 \\
SDM & $<===>$ & Adaptasi & 0,09 & 1,37 \\
SDM & $<===>$ & Sumberdaya BPP & 0,63 & 4,12 \\
SDM & $<===>$ & Petani binaan & 0,11 & 2,29 \\
Petani binaan & $<===>$ & Adaptasi & $-0,16$ & $-1,24$ \\
Petani binaan & $<===>$ & Sumberdaya BPP & 0,63 & 3,88 \\
Sumberdaya BPP & $<===>$ & Adaptasi BPP & 0,22 & 2,21 \\
\hline
\end{tabular}

(1997), yang mengemukakan bahwa pemimpin terlibat dalam empat jenis kegiatan: 1) membangun dan memelihara hubungan, (2) mendapatkan dan memberikan informasi, (3) orang yang mempengaruhi, dan (4) pengambilan keputusan.Bernard Bass dalam Terry (2002), pada Stogdill's Handbook of Leadership, bahwa kepemimpinan merupakan suatu interaksi antar anggota suatu kelompok. Para pemimpin adalah agen perubahan, orang yang tindakannya mempengaruhi orang lain lebih dari pada tindakan orang lain mempengaruhi mereka. Kepemimpinan terjadi ketika anggota suatu kelompok memodifikasi motivasi atau kompetensi anggota-anggota lain dalam kelompok tersebut.

\section{Pengaruh SDM pada Program Aksi BPP}

Penelitian ini memperlihatkan bahwa peubah Sumberdaya manusia (SDM) berpengaruh nyata pada program aksi BPP. Hal tersebut memberi pengertian bahwa SDM turut menentukan baik atau tidak baiknya program aksi yang dirumuskan dan diimplemantasikan dengan koefisien pengaruh sebesar 0,23 yang nyata pada $\alpha=0,05$. Pengaruh SDM pada program aksi terlihat pada kemampuan BPP merumuskan programa, fasilitasi RDK dan RDKK serta efisiensi pemanfaatan BOPP dalam menjalankan tugas dan fungsi staf BPP pada proses belajar yang diselenggaran oleh BPP. Hal ini mengindikasikan, jika terjadi peningkatan satu satuan SDM, akan meningkatkan program aksidalam merumuskan programa dan mengimplementasikannya sebesar 0,20 satuan, meningkatkan fasilitasi penyusunan dan perumusan RDK dan RDKK masing masing sebesar 0,25 dan 0,17 satuan, begitu juga BOPP akan semakin meningkatkan efektivitas penggunaanya dalam melaksanakan proses pembelajaran sebesar 0,40 satuan.

Sejalan dengan hasil penelitian ini, maka kedudukan dan fungsi SDM dalam organisasi sangat strategis, karena SDM merupakan motor penggerak sumberdaya lainnya agar organisasi tetap berjalan sesuai misi dan tujuan yang ingin dicapai. Hal itu dikemukakan Kontoghiorghes, Awbrey, Feurig (2005).Selanjutnya Russel dan Taylor III (2003) juga mengemukakan tentang SDM, dimana kedudukannya sebagai staf/karyawan yang memiliki kebutuhan dan keperluan untuk pengembangan sebagaimana yang diungkapkan bahwa isu strategis pada sumberdaya manusia meliputi penetapan tingkat keterampilan dan derajat otonomi yangdiperlukan untuk bekerjanya sistem produksi, menguraikan ukuran-ukuran pemilihan kebutuhan pelatihan, dan menentukan kebijakan atas evaluasi kinerja, ganti rugi, dan insentif.

\section{Pengaruh Petani Binaan pada Program Aksi BPP}

Hasil penelitian ini memperlihatkan bahwa peubah petani binaan berpengaruh nyata pada program aksi. Maknanya petani binaan turut menentukan seberapa baik perumusan dan juga implemenatasi 
program aksi BPP dengan koefisien pengaruh sebesar 0,17 nyata pada $\alpha=0,05$. Pengaruh peubah petani binaanpada program aksi tersebut dapat dilihat dari programa yang dirumuskan dan dijadikan dokumen perencanaan untuk diimplementasikan, kemampuan fasilitasi RDK dan RDKK secara terstruktur dan tuntas serta biaya operasional yang dikelola dengan baik pada saat menjalankan proses pembelajaran dan tugastugas fungsional lainnya. Hal tersebut menunjukkan; apabila terjadi peningkatan satu satuan peubah petani binaan, maka akan meningkatkanprogram aksi dalam meru-muskan programa penyuluhan sebesar 0,15 satuan, meningkatkan fasilitasi RDK dan RDKK masing-masing sebesar 0,11 dan 0,13 satuan.

Pengaruh petani binaan terhadap program aksi, dibentuk olehyang dicirikan besarnyajumlah kelompok yang ditangani oleh BPP dan luasnya wilayah kerja BPP yang dilihat seberapa jumlah desa yang menjadi WKBPP. Penciri peubah tersebut turut menentukan peubah petani binaan mempengaruhi program aksi. Hasil penelitian sejalan dengan Permentan RI-Lamp.3, 2007, bahwa implikasi kelompok dan WKBPPadalah pada penyeleggaraan kunjungan penyuluh pertanian kepada kelompok tani dilakukan selama 4(empat) hari kerja dalam seminggu, setiap penyuluh membina 8 -16 kelompok tani dan dijadwalkan mengunjungi setiap kelompok sekali 2 minggu. kunjungan kerja ini diharapkan seorang penyuluh pertanian dapat mempengaruhi 100 orang petani per kelompok. Dalam setiap wilayah kerja terdiri dari 8 -16 kontak tani sebagai ketua kelompok tani. Setiap 1 (satu) kontak tani mempunyai 5 (lima) orang petani maju, setiap petani maju mempengaruhi sampai dengan 19 orang anggota kelompok tani.

Peranan dari kelompok tani dapat diamati, bahwa perubahan perilaku petani melalui aktivitas individu, biasanya lebihlambat dibandingkan jika petani bersangkutan aktif dalam kegiatan kelompok (Samsuddin, 1987).

\section{Pengaruh Sumberdaya BPP pada Program Aksi BPP}

Hasil penelitian menunjukkan bahwa peubah sumberdaya BPP berpengaruh nyata pada program aksi BPP. Hal tersebut mengindikasikan sumberdaya BPP turut menentukan terumuskannya dengan baik program aksi BPPsebesar 0,54 yang nyata pada $\alpha=$ 0,05 . Pengaruh sumberdaya BPP pada program aksi tersebut dapat dilihat dari terumuskannya dengan baik programa BPP, terfasilitasinya pelaku utama dalam merumuskan dan menyusun RDK dan RDKK, termanfaatkannya BOPP secara efektif dan efisien. Hal ini mengindikasikan, jika terjadi peningkatan satu satuan sumberdaya BPP, akan meningkatkan program aksi dalam perumusan dan penyusunan programa penyuluhan sebesar 0,13 satuan, meningkatkan kapasitas fasilitasi RDK dan RDK sebesar 0,36 dan 0,41 serta BOPP sebesar 0,41 satuan.Sejalan dengan penelitian tersebut, maka secara umum konsep kinerja organisasi didasarkan pada gagasan bahwa organisasi adalah asosiasi sukarela dari asset produktif, termasuk manusia, sumberdaya fisik dan modal, untuk tujuan mencapai tujuan bersama (Carton dan Hofer, 2006). Begitu juga dengan apa yang dikemukan oleh Carton dan Hofer(2006) bahwa mereka menyediakan aset hanya untuk menjalankan organisasi mereka asalkan mereka puas dengan nilai yang mereka terima di bursa, relatif terhadap penggunaan alternatif aset. Lusthaus et. al., (2002) mengemukakan bahwa setiap organisasi harus berusaha memenuhi tujuannya dengan pengeluaran yang diterima dari sumberdaya sambil menjamin keberlanjutan jangka panjang.

\section{Pengaruh Adaptasi BPP pada Program Aksi BPP}

Penelitian ini memperlihatkan bahwa peubah adaptasi berpengaruh nyata pada program aksi BPP. Hal tersebut berarti adaptasi turut menentukan kemampuan terumuskannya program aksi yang baik dengan koefisien pengaruh sebesar 0,15 nyata pada $\alpha=0,05$. Pengaruh adaptasi terhadap program aksi tersebut diperlihatkan pada kemampuan BPP yang semakin meningkat kualitasnya dalam merumuskan programa, menfasilitasi perumusan dan penyusunan RDK dan RDKK serta kemampuannya memanfaatkan BOPP secara efektif dan efisien sehingga dapat diamanfatkan dengan baik dalam menjalankan proses belajar dan tugas-tugas lainnya yang diperintahkan noleh atasannya.

\section{Pengaruh Pengembangan BPP, Pengelolaan BPP, SDM, Petani Binaan, Sumberdaya BPP dan Adaptasi BPP pada Program Aksi BPP}

Hasil penelitian menunjukkan bahwa peubah pengembangan BPP, pengelolaan BPP, SDM, petani binaan, sumberdaya BPP dan adaptasi BPPberpengaruh 
nyata pada program aksi (Y1) dengan koefisien determinasi sebesar 72 persen yang nyata pada $\alpha=0,05$. Menunjukkan bahwa peubah pengembangan BPP, pengelolaan BPP, SDM, petani binaan, sumberdaya BPP dan adaptasi BPP secara bersama-sama berpengaruh pada program aksi (Y1) sebesar $72 \%$ dan sisanya $28 \%$ merupakan pengaruh peubah lain yang tidak termasuk dalam model.

Besarnya pengaruh peubah pengembangan BPP, pengelolaan pada BPP, SDM, petani binaan, sumberdaya BPP dan adaptasi BPP pada program aksi merupakan konstribusi nyata dari beberapa penciri peubah lainnya. Secara bersama-sama peubah penciri peubah-peubah laten dan endogen, yaitu: pengembangan BPP, pengelolaan BPP, SDM, petani binaan, sumberdaya BPPdan adaptasi BPP berpengaruh nyata pada program aksi BPP dengan koefisien determinasisebesar $72 \%$, sehingga terdapat pengaruh peubah diluar hasil penelitian, yaitu sebesar 28\%.Oleh karena itu, pengembangan BPP, pengelolaan BPP, SDM, petani binaan, sumberdaya BPP dan adaptasi BPP merupakan faktor internal yang dominan dalam mengembangkan program aksi yang dapat beefek pada perbaikan kinerja pengelolaan BPP.

\section{Pengaruh Pengembangan BPP, Pengelolaan BPP, SDM, Petani Binaan, Sumberdaya BPP dan Adaptasi BPPpada Perubahan Perilaku Petani}

Penelitian ini memperlihatkan hasil bahwa peubah pengembangan BPP, pengelolaan BPP, SDM, petani binaan, sumberdaya BPP dan adaptasi BPP berpengaruh nyata pada perilaku petani. Keenam peubah tersebut berpengaruh tidak langsung dan nyata pada perilaku petani. Dapat diakatakan bahwa pengaruh keenam peubah pada perilaku petani tersebut melalui program aksi, sedangkan peubah program aksi (Y1) berpengaruh langsung dan nyata pada perilaku petani dengan persamaan model struktural $\mathrm{Y} 2=0,78 \mathrm{Y}$ 1. Persamaan tersebut menunjuk kan bila terjadi peningkatan satu satuan program aksi, maka akan terjadi perubahan perilaku petani sebesar 0,78 satuan. Perubahan perilaku petani tersebut nampak pada peningkatan kompetensi petani sebesar 0,78 satuan dan sekaligus peningkatan partisipasi petani sebesar 0,78 satuan. Sedangkan koefisien determinasi program aksi pada perubahan perilaku petani sebesar $61 \%$, sisanya $39 \%$ merupakan pengaruh lain di luar penelitian ini.

Sejalan dengan hasil penelitian tersebut, Lionberger dan Gwin (1991) mengemukakan bahwa aktivitas penyelenggaraan penyuluhan pertanian adalah salah satu diantara sekian banyak faktor yang menyebabkan terjadinya perubahan perilaku petani. Selanjutnya va den Ban (1999) mengemukan dari sudut pandang penyuluhan untuk mempengaruhi perilaku manusia (petani) disebutkan beberapa unsur, yaitu upaya yang dilakukan untuk mempengaruhi perilaku manusia dengan jalan: (1) melalui pendidikan; (2) memberi bantuan, dan (3) melakukan paksaan kebijakan (hukum/undang-undang).

\section{Hubungan antar Peubah yang Berpengaruh pada Program Aksi BPP}

Hasil penelitian memperlihatkan (Tabel 2) bahwaterdapathubungan antarpeubah pengembangan BPP dan SDM, pengelolaan BPP dan SDM, SDM dan sumberdaya BPP, serta petani binaan dan sumberdaya BPP, tergolong kuat dengan koefisien hubungan di atas 0,50 satuan. Sedangkan pengembangan BPP dan adaptasi BPP, pengembangan BPP dan pengelolaan BPP, pengelolaan BPP dan juga sumberdaya BPP, pengelolaan BPP dan petani binaan sumberdaya BPP memiliki hubungan yang nyatapada $\alpha=0,05$ tetapi bersifat lemah. Berbeda dengan kelompok peubah tersebut, pengembangan BPP dan petani binaan, SDM dan adaptasi, SDM dan petani binaan, petani binaan dan adaptasi koefisien hubungannya tidak nyata pada $\alpha=0,05$. Hubungan tersebut dapat dijelaskan bahwa apabila terjadi perubahan pengembangan BPP pada dimensi tujuan dan sasaran dan pengelolaan BPP pada dimensi tata kelola dan kepemimpinan dan kaulaitas SDM pada dimensi rasio penyuluh dan petani, pelatihan teknis dan jumlah staf administrasi dan keuangan yang baik serta sumberdaya yang memadai akan meningkatkan faktor-faktor internal BPP.

Hubungan antar peubah pengembangan BPP dan petani binaan, SDM dan adaptasi, SDM dan petani binaan, petani binaan dan adaptasi koefisien hubungannya tidak nyata dan terbilang lemah dengan koefisien hubungan di bawah 0,50 satuan.

Hasil penelitian ini sejalan dengan pandangan Lusthaus et al. (2002)bahwa, kinerja organisasi dipengaruhi oleh tiga faktor, yaitu: kapasitas organisasi, motivasi organisasi dan lingkungan organisasi yang 
memiliki keterkaitan satu dengan yang lain. Kapasitas organisasi merupakan kemampuan dari suatu organisasi untuk menggunakan sumberdaya yang tersedia. Motivasi organisasi menunjukkan kepribadian dasar organisasi dan lingkungan eksternal merupakan faktor kunci dalam menentukan tingkat ketersediaan sumberdaya dan juga yang telah dapat menyelesaikan kegiatannya.

\section{Kesimpulan}

Berdasarkan hasil analisis dan pembahasan yang dipaparkan pada bagian sebelumnya, dapat disimpulkan hal-hal sebagai berikut: (1) Pengembangan BPP, Pengelolaan BPP, SDM, para Petani Binaan, Sumberdaya BPP dan Adaptasi BPP berpengaruh nyata pada program aksi BPP. Sedangkan faktor internal yang berpengaruh program aksi BPP adalah : tujuan, strategi, tata kelola, kepemimpinan, pelatihan teknis, rasio antara penyuluh dengan petani, jumlah tenaga administrasi dan keuangan, jumlah kelompok binaan, luas WKBPP, pembiayaan, sarana dan prasarana, sistem informasi, uji coba teknologi pertanian, pengembangan masyarakat dan kerjasama dengan lembaga lain. Semua faktor internal tersebut berpengaruh nyata pada kemampuan merumuskan program aksi BPP.(2)Pengembangan BPP, Pengelolaan BPP, SDM, Petani Binaan, Sumberdaya BPP dan Adaptasi BPP berpengaruh tidak langsung dan nyata pada perubahan perilaku petani, sedangkan program aksi melalui penciri pembentuknya, yaitu: programa, RDK, RDKK dan Biaya operasional berpengaruh langsung dan nyata pada perilaku petani. (3) Derajat hubungan antar peubah pengembangan BPP, Pengelolaan BPP, SDM, Petani Binaan, Sumberdaya BPP dan Adaptasi BPP tergolong lemah dan tidak berbeda nyata.

Derajat hubungan tergolong kuat adalah pada peubah pengembangan BPP dan sumberdaya BPP, pengembangan BPP dan SDM, pengelolaan BPP dan SDM, Sumberdaya BPP dan SDM serta petani binaan dan sumberdaya BPP, sedangkan derajat hubungan antar peubah pengembangan BPP dan adaptasi BPP, pengembangan BPP dan petani binaan, pengembangan BPP dan pengelolaan BPP, pengelolaan BPP dan adaptasi BPP, pengelolaan BPP dan sumberdaya BPP, pengelolaan BPP dan petani binaan, SDM dan adaptasi, SDM dan petani binaan, petani binaan dan adaptasi serta sumberdaya BPP dan adaptasi BPP tergolong lemah. (4) Program aksi BPP berdampak pada perubahan perilaku petani melalui dimensi programa penyuluhan, RDK, RDKK dan biaya operasional.

\section{Daftar Pustaka}

Babbie E. 1992. The Practice of Social Research. Sixth Edition, Balmont, California: Wadsworth Publishing Company.

Benowitz EA. 2001. Cliffs Quick ReviewTM: Principles of Management. New York: Wiley Publishing Inc.

Brewerton P, Millward L. 2006. Organizational Research Methods: A Guide For Students and Researchers. London: SAGE Publication Ltd.

Burton, RM, DeSanctis, Obel B.2006. Organizational Design: A Step-By-Step Approach. New York: Cambridge University Press.

Carton RB, Hofer CW. 2006. Measuring Organizational Performance: Metrics for Entrepreneurship and Strategic Mana-gement Research. Massachusetts 01060, USA: Edward Elgar Publishing, Inc.

Greiling D. 2007. Trust and Performance Management in Non-Profit Organiza-tions.The Innovation Journal: Public Sector Innovation Journal, Vol. 12 (3), 2007, article 9.

Leeuwis, van den Ban A. 2004. Communication for Rural Innovation: Rethinking Agricultural Extension. (third edition). Iowa USA: Blackwell Publishing Company. Parmenter D. 2010. Key Performance Indicators: Pengembangan, Implementasi, dan Penggunaan KPI Terpilih. Jakarta (ID): PT Elex Media Komputindo.

Lye JM. 2006. "Performance Measurement In The Public Sector: A Clarification And Agenda For Research."Journal Australian Accounting Review. Melbourne: Jul 2006. Vol. 16, Iss. 2; pg. 25, 9 pgs. http://proquest.umi.com

Lunenburg FC. 2010. "Schools As Open Syatem". Journal Schooling Number 1 Januari 2010 Volume1.http://www.nationalforum.com

Swanson RA, Holton III EF. 2005. Research in Organizations: Foundations and Methods of Inquiry. San Francisco: Berret - Koehler Publishers, Inc.

van den Ban AW, Hawkins HS. 1999. Penyuluhan Pertanian. Yogyakarta: Penerbit KanisiuWard 
Jurnal Penyuluhan, September 2012 Vol. 9 No. 2

J, Peppard J, 2009. Strategic Planning for Information System. England: John Wiley \& Sons, Ltd.

Rowe E. 2010. "Looking at Extension as a Learning Organization" Journal of Extension. Number 4 Volume 48 August 2010. http://www.joe.org / joe /2010august/rb1.php (11 April 2011). 